\title{
Water management and planning in a semi-arid country: the South African situation
}

\author{
J. Visser \& S.-A. Verhoog \\ Department of Water Affairs and Forestry, South Africa
}

\begin{abstract}
South Africa is a semi-arid country in which the average rainfall is well below the world average of about $860 \mathrm{~mm}$ per year. Stream flow in South African rivers is at a relatively low level for most of the time, a feature that limits the proportion of stream flow that can be relied upon to be available for use. As a result of historical imbalances of the past, the availability of water was to a large extent determined by the prosperity and race of the water user. This resulted in a situation where a small percentage of the population controlled the bulk of the industrial and agricultural water in the country. The National Water Act, promulgated in 1998, saw the beginning of a new era with a new water resource management policy. The following principles are inherent to the new policy: Equitable use of resources, efficient and optimal use of the resource and sustainable use of the resource. A water use licensing system was introduced and enforced by the National Water Act. One of the objectives of this said Act is to redress the imbalances of the past through a more transparent and justifiable process. The paper will attempt to describe the licensing procedure and describe how social, economical and ecological aspects are influencing the decision-making processes in the management of water resources in South Africa.

Keywords: arid country, historical imbalances, redress, equitable access, sustainability, resource protection, beneficial use, public interest.
\end{abstract}

\section{Introduction}

South Africa is largely a semi-arid country with a varied climate. A gradual change in climatic conditions occurs from the wet and sub-humid eastern regions to the arid western coastal belt along the Atlantic Ocean. The average annual 
rainfall in the eastern coastal area reaches $1200 \mathrm{~mm}$ whereas the coastal plains on the west coast receive rainfall well below $100 \mathrm{~mm}$. In the south, the presence of the east-west stretching Cape mountain ranges, up to $2000 \mathrm{~m}$ high, has an orographic effect on rainfall with the mountains receiving up to $2000 \mathrm{~mm}$ and the valleys only between 200 and $300 \mathrm{~mm}$. The mean annual rainfall is $460 \mathrm{~mm}$ compared to a world average of $860 \mathrm{~mm}$ per annum. Water use in South Africa is dominated by irrigation, which uses approximately $60 \%$ of all water in the country. Domestic and urban use accounts for about $11 \%$ of water use, while mining and some large industries account for approximately $8 \%$. Commercial forestry plantations use around $8 \%$ by reducing runoff into rivers and streams. Due to the rainfall pattern, access to water is vital, especially for the agricultural and industrial sectors of the economy.

\section{The legacy of apartheid and previous water legislation}

Although water distribution in South Africa is geographically unequal, it is even more unequal when measured in terms of race and gender. Legislation in the past benefited riparian land-owners and together with the policy of racial segregation ("Apartheid") this lead to a situation where it was virtually impossible for black people to own riparian land. Black people were to a large extent excluded from financial means and they did not have any political rights. In a male dominated society it was inevitable that white males had access to most of the water that was necessary for agricultural and industrial development.

As far as the provision of water for basic human needs is concerned, white people also received preferential treatment. It has been estimated that in 1994, twelve (12) million people in South Africa did not have adequate access to clean water within a reasonable distance from their houses, and therefore could not afford the quality of life and health benefits concerning the provision of water and sanitation.

Apart from social issues, there were also other challenges that had to be addressed in the new South Africa. Under the previous Water Act (Act 54 of 1956) groundwater was seen as "private water". This meant that anybody that had a good source of underground water on his/her property could exploit that source without any consideration of other water users and the ecology. There was a lack of understanding concerning the influence that groundwater may have on surface water. Each must therefore be managed with regard to its interrelationship with the other.

It must also be mentioned that under the previous Water Act the environment did not always get its fair share of water and the perception was that the environment (or the ecology) could be neglected.

\section{The need for change}

Being an arid country, pressure on resources became critical in the 1980s and 1990s. It became clear that legislation and policies of the past had to be amended in order to provide for the needs of a developing society with due consideration 
of the environment. In 1994 a new democracy was established in South Africa. The new Constitution (1996) guaranteed everyone the right to have the environment protected while promoting justifiable economic and social development, the right to access to sufficient food and water and the right to dignity. The review of the water law was guided shortly after this through a wide public participation process, culminating in a set of basic principles. These principles were embodied in the White Paper on National Water Policy, 1997, as a statement of Policy and followed up by enacting it in legislation with the Water Services Act, 1997, and the National Water Act, 1998. Three fundamental objectives for managing South Africa's water resources arise from these principles:

To achieve equitable access to water, including access to water services, to the use of water resources, and to the benefits from the use of water resources.

To achieve sustainable use of water, by making progressive adjustments to water use to achieve a balance between water availability and legitimate water requirements, and by implementing measures to protect water resources.

To achieve efficient and effective water use for optimum social and economic benefit.

The South African National Water Act provides the foundation for water to be managed in South Africa in an integrated manner based on the above principles. The integrated nature and interdependence of water in all its forms within the total water cycle form the basis of management on a catchment or watershed level. A drastic change in the philosophy and practice of water resource management was vital to address the new constitutional obligations and a new approach to the management of water was put in place.

\section{Principles of the National Water Law}

The water law reform process developed key principles through a wide public participation process before it were entrenched in the National Water Act in 1998. Some of the principles that guided the revision of the water law, the concepts endorsed and instruments provided in the Water Services Act and National Water Act are highlighted.

Principle 1: The water law shall be subject to and consistent with the Constitution in all matters including the determination of the public interest and the rights and obligations of all parties, public and private, with regards to water. While taking cognisance of existing uses, the water law will actively promote the values enshrined in the Bill of Rights.

Principle 2: All water, wherever it occurs in the water cycle, is a resource common to all, the use of which shall be subject to national control. All water shall have a consistent status in law, irrespective of where it occurs.

Principle 3: There shall be no ownership of water but only a right (for environmental and basic human needs) or an authorisation for its use. Any authorisation to use water in terms of the water law shall not be in perpetuity. 
Principle 4: The location of the water resource in relation to land shall not in itself confer preferential rights to usage. The riparian principle shall not apply.

Principle 7: The objective of managing the quantity, quality and reliability of the nation's water resources is to achieve optimum, long term, environmentally sustainable social and economic benefit for society from their use.

Principle 8: The water required to ensure that all people have access to sufficient water shall be reserved.

Principle 9: The quantity, quality and reliability of water required to maintain the ecological functions on which humans depend shall be reserved so that the human use of water does not individually or cumulatively compromise the long term sustainability of aquatic and associated ecosystems.

Principle 10: The water required to meet the basic human needs referred to in Principle 8 and the needs of the environment shall be identified as "the Reserve" and shall enjoy priority of use by right. The use of water for all other purposes shall be subject to authorisation.

Principle 20: The conditions upon which authorisation is granted to use water shall take into consideration the investment made by the user in developing infrastructure to be able to use the water.

Principle 25: The right of all citizens to have access to basic water services (the provision of potable water supply and the removal and disposal of human excreta and waste water) necessary to afford them a healthy environment on an equitable and economically and environmentally sustainable basis shall be supported.

The water required for basic human needs and the aquatic needs of the environment enjoy priority of use while use of water for all other purposes is subject to authorisation. The degree of utilisation that can be sustained by a water resource must be recognised and respected. This depends on maintaining a basic level of ecological integrity and function. The Act recognises this basic level as the Reserve. The Reserve is intended to protect the resilience of water resources, to satisfy basic human needs by securing a basic water supply and to protect aquatic ecosystems in order to secure ecologically sustainable development and use of the water resource. The ecological reserve or resource base, i.e. the quantity, quality and reliability of water required to maintain the ecological functions on which humans depend, should be reserved so that the human use of water does not individually or cumulatively compromise the longterm sustainability of aquatic and associated ecosystems. The Reserve is not intended to protect the aquatic ecosystem at the expense of all development but at levels that are sustainable in the long term. In addition, aquatic ecosystems that are particularly fragile or important can receive additional protection. For this, the Act provides for ecological categories in assessing the Reserve, a management classification system, and resource quality objectives. The purpose of the Water Conservation and Water Demand Management Strategy is to improve the efficient and effective use of water and minimize loss or waste of water in order to achieve sustainable, efficient and affordable water supply to all consumers. The emphasis has shifted away from the traditional primary focus on the development of additional water sources to new approaches which focus on 
the way water is used and how it can be conserved in each user sector. Water pricing and demand management will become some of the most important policy instruments in support of water conservation.

\section{Water use authorisation or licensing}

Use of water for all purposes will be subject to formal authorisation that will impose limits and restrictions. The following water uses are controlled:

a) Taking water from a resource

b) Storing water

c) All aspects of the discharge of wastes into water resources, including:

- Impact on a water resource;

- Disposing in any manner of water containing waste from, or which has been heated in any industrial or power generation process;

- Removing, discharging or disposing of water found underground if it is necessary for the efficient continuation of an activity or for the safety of people;

d) Making changes to the physical structure of rivers and streams:

- Impeding or diverting the flow of water in a watercourse;

- Altering the bed, banks, course or characteristics of a watercourse;

e) Certain activities which may affect the quantity or quality of water in the resource:

f) Engaging in a stream flow reduction activity - at present commercial forestry;

g) Engaging in a controlled activity - at present irrigation with water from waste treatment plants;

h) Using water for recreational purposes.

Provision is made for the continuation under certain conditions of an existing water use derived from previous legislation. An existing lawful water use, with any conditions attached, is recognised but may continue only to the extent that it is not limited, prohibited or terminated by the National Water Act. No licence is required to continue with an existing lawful water use until a responsible authority requires a person claiming such an entitlement, to apply for a licence. If a licence is issued it becomes the source of authority for the water use. If a licence is not granted the use is no longer permissible.

\section{Considerations for water use authorisations and licences}

Section 27 (1) of the National Water Act states that the following factors must be taken into account when issuing authorisations or licences:

(a) existing lawful water uses;

(b) the need to redress the results of past racial and gender discrimination;

(c) efficient and beneficial use of water in the public interest;

(d) the socio-economic impact -

(i) of the water use or uses if authorised; or

(ii) of the failure to authorise the water use or uses; 
(e) any catchment management strategy applicable to the relevant water resource;

(f) the likely effect of the water use to be authorised on the water resource and on other water users;

(g) the class and the resource quality objectives of the water resource;

(h) investments already made and to be made by the water user in respect of the water use in question;

(i) the strategic importance of the water use to be authorised;

(j) the quality of water in the water resource which may be required for the Reserve and for meeting international obligations; and

(k) the probable duration of any undertaking for which a water use is to be authorised

When a water use licence application is received, the following factors (in descending order of importance) are normally observed.

- Provision for the Reserve.

- International agreements and obligations.

- Water for social needs such as poverty eradication, primary domestic needs, and uses which would contribute to maintaining social stability.

- Water for key economic sectors and employment creation. This includes key industries, power generation and commerce.

- Most water use thereafter (which includes commercial forestry) can be classified as general economic uses, where allocation should best be dictated by the economic efficiency of water use.

- Uses of water not measurable in economic terms, which may include convenience uses and some private water use for recreational purposes, are likely to be of lowest priority.

\section{The licensing process}

The licensing process commences when an applicant approaches the department for a license to use water. The necessary forms and guidelines are then made available to the applicant.

The applicant is requested to provide information on aspects like the volume of water that is needed, existing water use in the relevant catchment area, the quantity and quality of water available in the catchment, the likely effect on other water users, the impact on the environment, the socio-economic impact on other water users and the redressing of the results of past racial and gender discrimination.

The department then determines the Reserve for that catchment, which provides for basic human needs as well as the protection of aquatic ecosystems. With all this information it is possible to determine whether any surplus water is available for further allocation.

As the allocation of water is not only dependent on physical or hydrological factors, the department developed a framework that takes the following aspects into account: 
- The promotion of redress (race and gender).

- The achievement of sustainable and equitable development.

- The support of poverty eradication and economic development.

- Ensuring resource protection in balance with equity and growth.

In the consideration of licence applications the objective is therefore to promote beneficial use in the public interest. This is done through a weighing system that reflects the relative importance of different elements of an application.

A low impact water use with high public interest is normally covered by Schedule 1 of the National Water Act or by general authorisations, which means that no authorisation is needed. Lower public interest with higher impact requires a licensing process that can vary depending on the degree of complexity.

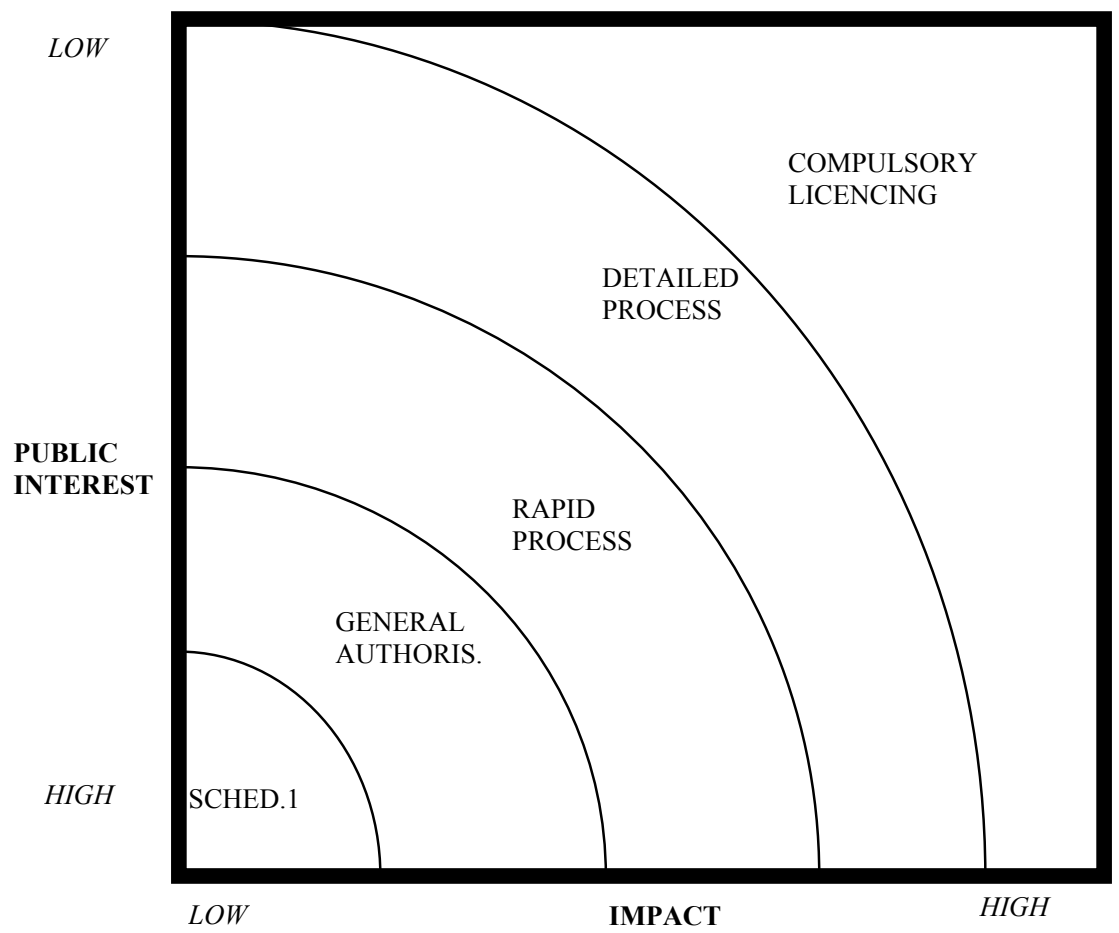

Figure 1: The relation between public interest and the impact on water resources.

In areas which are, or are soon likely to be, under "water stress" (for example, where the demands for water are approaching or exceed the available supply, or where the water resource is under threat), or where it is necessary to review prevailing water use to achieve equity of access to water, a process of compulsory licensing will be introduced. It includes preparation of schedules for allocating quantities of water to existing and new users. In such cases the 
department must publish a notice in the appropriate media, requiring people to apply for licences in the designated area. Applicants may be required to submit additional information, and may also be required to undertake an environmental or other assessment, which assessment may be subject to independent review.

In determining the quantities of water to be allocated to users, the department must consider all applications received, and draw up a schedule detailing how the available water will be allocated among the applicants. In drawing up an allocation schedule the department must comply with the plans, strategies and criteria set out elsewhere in the Act and must give special consideration to certain categories of applicants. A responsible authority need not allocate all the available water in a water resource, and may reserve some of the water for future needs. Provision is also made for any water still available after the requirements of the Reserve, international obligations and corrective action have been met to be allocated on the basis of public auction or tender. A system of objections and appeals in relation to proposed and preliminary allocation schedules ensures that licences may be issued only after the allocation schedule has been finalised.

In the figure 1 the relation between impact and public interest is presented diagrammatically.

\section{Conclusion}

The Department of Water Affairs and Forestry in South Africa has started a process that will require a good deal of dedication, commitment and hard work. This will hopefully lead to a situation where people will realise that water is a natural resource that belongs to all people and to achieve the sustainable use of water for the benefit of all users. It must also lead to a recognition of the need for the integrated management of all aspects of water resources.

\section{References}

[1] Department of Water Affairs and Forestry, You and Your Water Rights A call for Public Response, 1995.

[2] Department of Water Affairs and Forestry, Fundamental Principles and Objectives for a New Water Law in South Africa, 1997.

[3] Department of Water Affairs and Forestry, White Paper on a National Water Policy for South Africa, 1997.

[4] Department of Water Affairs and Forestry, National Water Act, 1998, Act 36 of 1998, Government Gazette, Vol. 398, No 18182, 26 August 1998.

[5] Department of Water Affairs and Forestry, Proposed First Edition of National Water Resources Strategy - Summary, Government Gazette, Vol. 446, No 23711, 6 August 2002.

[6] Department of Water Affairs and Forestry, Water Services Act, 1997, Act 108 of 1997, Government Gazette, Vol. 390, No 18522, 19 December 1997.

[7] Department of Water Affairs and Forestry, Framework on Water Allocation Reform, 2005. 